\title{
A SHIFT IN CORPORATE SOCIAL RESPONSIBILITY PROGRAM TO SUPPORT VOCATIONAL EDUCATION IN INDONESIA
}

\author{
Mgs. Ahmad Ramadhani ${ }^{1,}$ " and Ety Rahayu ${ }^{2}$ \\ ${ }^{1,2}$ Department of Social Welfare, Faculty of Social Sciences \& Politics, Universitas Indonesia, Depok, \\ Jawa Barat 16424, Indonesia \\ E-mail: purnamaperak@gmail.com * \\ *Corresponding Author
}

\begin{abstract}
The high unemployment rate in Indonesia can be alleviated through Corporate Social Responsibility (CSR) program in the education sector. This paper is aimed to examine how could that figure derived from vocational school graduates be reduced by the program in education that taking an opportunity from current several regulations issued by central government and competency-based human resources development to equip students and graduates with a set of competencies hence they will be competent and able to compete in the job market. This article was produced by using a systematic literature review method to explore and provide an overview of CSR program shifting in the education setting. The authors recommended the switch from a traditional or philanthropic model to a contemporary or strategic one by deploying internship, apprenticeship, and teaching factory to surmount the aforementioned issue. Finally, this paper offers managerial implication in general and suggestion for future academic research to explore and to assess their effectiveness in tackling poverty and impact on corporations, schools, and students or graduates.
\end{abstract}

Keywords: competence, corporate social responsibility, vocational education

\section{INTRODUCTION}

Unemployment is one of the big problems in many countries, including Indonesia. Of a population of more than 268.57 million, the workforce in August 2019 totaled 133.56 million people. However, there were only 126.51 million people employed and 7.05 million unemployed. The level of open unemployment was mostly supplied by vocational school graduates. In August 2019, the dominance of vocational school graduates in the open unemployment figure was $10.42 \%$ [1]. This is due to the low quality of graduates [2], and the irrelevance between the competencies developed and the superiority of the regions (regency/ municipality) [3].

The issue of unemployment is further entangled by entering the industry 4.0 era which is characterized by rapid and massive technological developments and is very closely related to the IoT (Internet of Things). On the one hand, technological disruptions give some benefits, but on other hand provide challenges for example automation or workers displacement by machines [4]. Although automation and digitalization are deemed to support humans instead of replacing them [5], or only a few works will be eliminated [6], the condition we perceive today is definitely different in that there are numerous types of jobs emerging, machines on the production line or technology replace humans, digital or Information Technology based companies that only consist of a few people make millions of dollars. The reason for the replacement of humans by technology such as robots because they show the ability to replace human labor, not only in routine tasks requiring low skills but also in jobs requiring high and complex skills [7].

Failure to mitigate graduates who are not ready to face this will increase the unemployment rate and unable to compete with other countries amid free-trade partnerships allowing labor mobility within the region, which absolutely will have an impact on people's welfare. This trend and situation, combined with the condition of vocational institutions and their graduates, need to be taken into account by the government and industries as partners of 
vocational schools. With the advantages of Vocational Education and Training (VET) flexibility to adjust the curriculum to follow current technological developments, market, and industry needs, it can direct graduates quickly absorbed to the job market or moreover be entrepreneurs making their own businesses and eventually reduce the number of unemployment [8]. Therefore, a movement or program to prepare competent human resources who are ready to work, competitive, and able to adapt is paramount required.

VET is an education system that offers a dynamic and responsive education to the needs of the labor market which is different from science-oriented high schools whose graduates are prepared to enter the tertiary level. With the characteristics of VET, the orientation of the school is directed at work education or technical education which is always dynamic. The concept of education has 3 interrelated components, namely learning for work, learning about work, and understanding the nature of work [9]. VET is different from other education that is shown by its characteristics to prepare students to enter the workforce, based on the needs of the world of work (demand-market driven), mastery of the competencies needed by the market, student success in hands-on or work performance, close relations with industry is the key to successful vocational education, responsive and anticipatory to technological development, learning by doing and hands-on experience, requiring the latest facilities for practice, greater investment and operational costs than general education [9].

With all these attributes, VET is expected to be a solution to the needs of skilled workers. To implement this, collaboration from various parties is needed. There are 3 strategies in social development to be implemented which are carried out by individuals, communities, and government [10]. Despite the view that social development is best carried out by governments, special agencies, policymakers or administrators because the state is responsible for the welfare of its citizens, the implementation of social development requires all three strategies to be carried out together [11]. Similarly, collaboration among parties was emphasized by the Sustainable Development Goals (SDGs) in achieving sustainable development success [12].

The role of companies or industries is might be shown by the Corporate Social Responsibility (CSR) program because it is a strong catalyst for the private sector's contribution to sustainable development [13]. A company with all its stakeholders can work together exploring options for development efforts and ensure its actions are in line with shareholder values [14]. Since organizations have a relationship with the surrounding communities in which they operate, community involvement and community development are inseparable parts of sustainable development [15]. Therefore, the organization must consider it as part of the community, recognize and respect the rights of the community in any decision making related to the community, recognize and respect community characteristics such as culture, religion, tradition, and history, and recognize the value of cooperation and support exchange resources, experience and effort.

This article applied an extant literature review explaining unemployment reduction especially in vocational graduates and in the disruptive era through Corporate Social Responsibility (CSR) in VET. In doing so, the research question is how could the unemployment rate derived from vocational school graduates be reduced by the CSR program? Building on prior VET and CSR researches, we focus on providing a proposal for future research and business practice in reducing unemployment through comprehensive and impactful educational CSR strategies. To address that question, the paper proceeds as follows: regulation opportunity to deal with the issue, CSR in VET to overcome the issue by implementing some models: internship, apprenticeship, teaching factory. 


\section{METHOD}

The research method of this study is a systematic literature review that motivated to depict knowledge to guide professional practice, to identify effective research methods, to identify experts within a given field, and to identify unpublished sources [16], [17]. Data were collected to answer the aforementioned research question by searching electronic databases as well as manually searching the archives of journals and on Google to identify relevant studies with combination keywords included corporate social responsibility, education, vocational education and training, and poverty. Each article was determined whether relevant or not for the research by reviewing title, keyword, abstract, introduction, and scope.

\section{RESULTS AND DISCUSSION}

\section{Regulation Opportunity}

To deal with the above issue, the Indonesia government has issued several related policies such as the Presidential Instruction No. 9 of 2016 concerning the revitalization of vocational high schools in an endeavor to improve human resources quality [18], the Regulation of the Minister of Industry no 03/M-IND/PER/1/2017 concerning guidelines for guidance and development of competency-based vocational high schools that link and match with industry [19], and the Government Regulation no. 45 of 2019 concerning the amendment to the Government Regulation No. 94 of 2010 concerning the calculation of taxable income and settlement of income tax in the current year [20].

The Presidential Instruction No. 9 of 2016 was aimed at 12 Ministers of the Cabinet, Head of the National Professional Certification Agency (BNSP), and 34 Governors to take the steps needed to revitalize vocational schools to improve the quality and competitiveness of human resources, to map out manpower needs from vocational school graduates, to plan development of VET, to improve and synchronize curriculum, to enhance partnerships, and others which all lead to the improvement of quality and competitiveness of vocational school graduates to enter labor market [18]. The Regulation of the Minister of Industry no $03 / \mathrm{M}-\mathrm{IND} / \mathrm{PER} / 1 / 2017$ is a guideline for vocational schools to organize competency-based vocational education programs that link and match with industries and for companies to facilitate VET to produce a competent workforce [19].

Both policies are expected to revitalize vocational institutions to prepare competent workers who are ready to work thus can support economic growth and reduce unemployment. Both require cooperation and support from all parties such as ministries, governors of each province, BNSP in improving the quality of human resources and establishing cooperation with industries as recipients of the graduates and its main partners. These policies are implemented by mapping out the development of vocational schools, synchronizing curriculum to industrial needs, increasing cooperation among stakeholders, increasing accreditation and access of competency certification for graduates, accelerating the provision of vocational teachers, encouraging industries or industrial estates to provide support in developing teaching factories and infrastructure such as workshops and laboratories as well as providing guidance to vocational schools, making it easy for students to practice at the Job Training Center (BLK), industries, or other institutions. This Presidential Instruction is monitored and evaluated at least biannually and is directly reported to the President. For industries or industrial estates that conduct vocational training and development as stipulated in the Minister of Industry Regulation, they are promised to be given incentives.

Three years after the Presidential Instruction had been issued, the government through the Government Regulation no. 45 of 2019 approved the $200 \%$ tax deduction for companies conducting training, apprenticeship, 
and or competency-based human resources development [20]. This policy was a breath of fresh air for companies to contribute in assisting vocational schools to improve their students' or graduates' competencies [21].

In addition to the three regulations above, especially the Government Regulation no. 45 of 2019 which encourages companies contributing to developing competency of vocational graduates, the Indonesian government also has stipulated companies to carry out CSR in general. There is a view that regardless of the benefits obtained or the relationship between the company and the community, the law is a fundamental aspect underlying it. Law is important in structuring and enabling the achievement of corporate objectives, an important tool of government and social control, and it is more sophisticated than voluntarymandatory dialogue that encompasses CSR [22]. The obligation to carry out legally regulated CSR (mandatory CSR) is more effective than voluntary [23]. Some regulations related to CSR are such as Law no. 40/2007 concerning limited liability companies [24], Law no. 25/2007 concerning investment [25], Government regulation no. 47/2012 concerning social and environmental responsibility of limited liability company imposing a mandatory CSR regime on natural resource-based and natural resourcerelated companies [26].

\section{CSR in VET to Improve Competencies}

Support of companies to overcome the unemployment issue can be delivered by deploying CSR educational programs to equip vocational students and graduates with adequate competencies that are in line with the demands of the 4th industrial revolution. Instead of companies implementing CSR philanthropic programs for examples by donating learning tools, funds for building construction, and scholarships, which is difficult to sustain [27], companies can challenge their management to shift from the traditional CSR model satisfying legal or social requirements to more contemporary or strategic model for instance by incorporating business practices and empowerment programs into VET to improve and prepare future competencies. The future of CSR has also to take into account the newest technology and their role as part of new business frameworks and strategies [28]. The examples of this program are curriculum synchronization, teacher internship, student internship, alumni apprenticeship, and teaching factory [29][30] . Companies' involvement in apprenticeship programs can be seen as (1) a strategic business decision, (2) a way of giving back to the community, or a combination of both [31].

These kinds of programs have to be taken into consideration because prosperous responses of the vocational systems towards the industrial revolution should focus on curriculum development, teacher training, and workers [32]. Similarly, to adapt to the rapid technological changes, VET must train individuals to meet industry needs, give students the proper and sufficient information related to the needs of this era, and school curricula need to be re-audited to match the development of the industry [33]. The companies' involvement in designing curriculum and deploying relevant training programs may assist to improve the effectiveness of education systems across many contexts [34].

Three models adopted by companies in carrying out CSR activities in the field of education are companies conceptualizing initiatives and implementing them themselves or with partners such as Non-Government Organizations (NGOs); companies providing financial or material support to develop initiatives in education carried out by NGOs, governments, or other companies; and companies assisting third-party such as governments, other companies, or multilateral organizations in designing and implementing development initiatives [35]. The strategies to implement these are as follows [35]: (1) identify areas of intervention or involvement and scope of work, (2) identify beneficiaries (demographic profile such as location, sex, category, age, type 
of school), (3) identify funding resources to create a sustainability model (internal, external, donor involvement model), (4) design a dedicated team with the right organizational structure to deploy the program (endorsing the organizational structure, recruiting core personnel, recruiting local personnel or volunteers), (5) identify key stakeholders of the program, (6) formulate the strategic plan of the program (setting goals, mapping resources, awareness programs, training for members), (7) mechanisms for monitoring and tracking success (financial monitoring, impact assessments at regular intervals, internal mechanisms for measuring or reporting on the expense of donor funds, reporting mechanisms to donors, mechanisms for getting feedback, identifying tools used to save reports), and (8) ensure sustainability and replicability models.

\section{Internship and Apprenticeship}

Employment in the recent global economy which is based on information demands the importance of new competencies thus education is not enough just at the stage of knowing (understanding), but also must achieve the ability of Higher Order Thinking Skills (HOTS), specifically applying, analyzing, evaluating or critical thinking, and problem-solving [36]. To acquire these skills, it is not enough to only learn in the class or with conventional unstructured internship or apprenticeship programs that resulted in unabsorbed graduates in the labor market due to the mismatch between required and actual competencies. Therefore, to overcome the unsynchronized skills possessed by workers with current and future needs, it can be done by conducting well-organized internship or apprenticeship that targeting the skills required in the future, making reskilling the existing workforce as part of change management and future workforce planning efforts and rethinking the education system which currently still implements the 20th century method which is less sensitive to the need for expertise and the labor market [37].
Learning by doing or problem-solving is the foundation of vocational education and apprenticeship [38]. Apprenticeship in vocational education is known in several terms that are similar but contain different meanings such as internship, or in Indonesia so-called Prakerind (Practice in Industry), and apprenticeship. Internship in Indonesia is stipulated in education regulations such as Law no. 20 of 2003 concerning the national education system [39], and the Ministry of Education and Culture Decree no 323/u/1997 concerning the implementation of dual system education at vocational school [40], while apprenticeship is stipulated in labor regulations such as Law no 13 of 2003 concerning manpower [41] and the Ministry of Manpower regulation no 6 of 2020 concerning the implementation of apprenticeships in the country [42]. However, the implementation of dual system education and Prakerind or internship are two different things. The former is conducted by assigning students to the industrial premises for several days a week in a period of several months, while the latter students practice full time there for several months.

An internship is one of the learning practices by being present at work in the company and working there for a short time, usually several weeks to several months, with or without pay [43]. Internships become part of the curriculum in the vocational education to stimulate students and facilitate them to get exposed to the industry thus they will be more active in learning [44]. Another definition, an internship is a structured work and career-related experience obtained by students before graduating from an educational institution [45] that not only offers opportunities for students to apply what is gained in the classroom but also masters various career-related skills such as time management, self-discipline, and communication [45].

The apprenticeship is more structured learning in the workplace and in a longer period, usually up to years, and leads to qualifications [43]. Apprenticeships have a character that is 
related to the legal, contractual rules and relationships with work status associated with rights at work and a combination of formal and informal education processes that help socialize workers in certain workplaces and work cultures [38]. Apprenticeships are based on contracts whose important elements such as duration of work practices required by apprentices; duration of training required by the trainer; allowance payment schedule; length of the probation period; apprentice training schedule; the number of hours in class; practice to be carried out; the amount of allowance; apprenticeship status; and union requirements [46]. According to Ministry of Manpower regulation no 6 of 2020, an apprenticeship agreement must contain at least rights and obligations of the apprentice; rights and obligations of the organizer; apprenticeship program; duration of the program, and the amount of allowance [42].

There are four things related to apprenticeships namely pedagogy, work, location, and social [47]. The main feature of apprenticeships is the placement of apprentices in experienced communities in which they interact and learn in a variety of ways. This is in line with the other opinion that apprenticeship learning will not be effective unless there are both work involvement and interaction with trainers and coworkers [48]. Furthermore, two factors influencing learning in the workplace are contextual factors such as allocation and structure of work, relationships with others at work, individual participation and expectations on performance; and learning factors, such as challenges and values from work, support for feedback and trust, confidence, commitment and motivation [49]. In an internship or an apprenticeship, the key to producing highly skilled labor is through practice with classroom learning as a supplement. On the Job Training (OJT) requires interns or apprentices to formulate their own learning opportunities. During OJT, interns or apprentices learn in 3 ways, especially when they do something with tools and materials; when they act with initiative; and when they learn by becoming part of the community of practice [50].

Research and news have revealed that the condition often occurred in industrial and school partnership in Indonesia was that companies admitted students for Prakerind/ internship without proper training or just basic task assignment that less relevant with training objectives [51][52]. If it is deployed properly, companies can obtain some production value from the apprenticeship period and a return of investment in the form of recruitment [31]. In terms of recruitment, the company can use this as candidates prescreening and reducing the cost of recruitment and training without entering a formal employment process [53]. Furthermore, such programs allows the employees to improve their skills in coaching, mentoring, and management that could promote engagement and job satisfaction [53].

Therefore, the implementation of CSR in the form of this strategy can be carried out as follows (1) work with schools to synchronize school curricula to meet the industry needs, (2) prepare the infrastructure for learning that is at least equivalent to the conditions in the company or current technology, (3) prepare internship or apprenticeship learning program comprising activities of classes, OJT, and assessment, (4) assign dedicated trainers, mentors, companions, who are experts in the company such as engineers, technicians, operators, and trainers, to assist interns or apprentices learn at work, (5) accept several interns or apprentices for a certain period to study at company premises mastering existing competencies in the industry or future projections, (6) accept teacher intern as they need to improve their competencies and to adapt to technological development as well, (7) deploy trainer visit to the school introducing new knowledge and technology.

\section{Teaching Factory}

With the development of increasingly advanced industries, a new approach to 
education is needed that can modernize the teaching process and draw closer to industrial practices, improve industrial practices through new knowledge, support the transition from manuals to future knowledge workers and bridging the gap between resource-based manufacturing (capital and labor) and knowledge-based manufacturing (information and knowledge), and form and maintain stable industrial growth [54]. A teaching factory can be a solution for this by integrating education, research, and innovation activities into a single initiative that effectively involves industries and schools. The teaching factory can integrate the three fundamental aspects and interconnected drivers in a knowledge-based society that is research, education, and innovation [55].

The teaching factory paradigm comprises industrial projects, relevant educational approaches, and ICT (Information and Communications Technology) configurations needed to facilitate interaction between industry and academia [55], [56]. The teaching factory program is a production or service-based learning concept referring to the industry standards and procedures that are carried out in an atmosphere like what happens in the industry [36]. This is a production-based learning process to produce goods or services that are following the market or consumer demands with actual work procedures and standards whose results can be utilized by the community, schools, or consumers. This proves that vocational students are not only competent but also able to apply their competencies to something useful.

The teaching factory aims at two-way knowledge communication between academia and industry in real-life industry applications. This paradigm provides a real environment for students and engineers to develop their skills and understand the challenges in everyday industrial practices [56].

From an academic point of view, the teaching factory scheme is a new experience for students and instructors who provide new teaching that is not available in theoretical teaching or the laboratory. The teaching factory allows students to deepen their knowledge and practice, overcome real problems, and work within the time limit and scope of industrial practices. Finally, their work will have a real impact outside the academic environment [55].

The concept of teaching factory originated from medical disciplines, in the hospital teaching paradigm [55], [56]. This concept was adapted from the dual system learning method in TVET (Technical Vocational Education and Training) in Germany and Switzerland. This program is also a combination of learning CompetencyBased Education and Training (CBET) and Production Based Education and Training (PBET) [36].

Through this CSR of teaching factory, companies can empower schools because it increases the competence of students and teachers through practicing with industrial products, provides profit to schools from orders being produced, and introduces business processes to schools. Activities of this for instance donating a set of machines in the plant, teaching teachers and students how to produce some products, purchasing those products or assisting school selling them, and assisting them in machines maintenance. The company might conduct this in two different ways which are on company premise or in the school area.

\section{CONCLUSION}

Shifting CSR in the field of education programs from traditional to contemporary through an internship, an apprenticeship, and teaching factory which could be categorized as socially responsible business practices [57], is expected to advance vocational education to increase the competence of graduates who are ready to work and adapt to the advances in existing technology. By quickly absorbed into the job market, the unemployment rate is expected to decrease while the level of welfare increases.

By carrying out those programs, companies are expected to not only show and prove their social responsibilities, but more than 
that also can benefit from it. This is what is called as contemporary CSR [58] which is responsible behavior as an opportunity to generate profits while at the same time meeting the expectations of the community. Impacts generated from this program for example costsaving in recruiting a competent workforce, cost -saving in training, shorter lead time in training and preparing the competent workforce, cost saving in producing products or services, improving company image, and increasing employee morale.

Through the implementation of this CSR education model, both companies and schools can prepare an adaptive workforce in technological development as well. With the fact that schools have limitations in preparing the cutting-edge technology, machinery, and tools that hinder the learning process, this can be a solution for schools to overcome this. The graduates will be more literate about technology development, competent in the job using existing technology, and be ready to master new skills required in the future.

As a literature review, this paper is limited to publications referring to CSR, VET, and poverty alleviation. The findings revealed that there is a link among them and suggested program shift to have a better impact. Moreover, it has practical contribution for company stakeholder to address their social expectation of improving social well-being and to organize the successful program reflecting their values, characteristics, and needs. From this review, there is a possibility of future research to investigate the effectiveness of each program and its impacts from the perspective of CSR.

\section{REFERENCES}

[1] Badan Pusat Statistik, "Keadaan ketenagakerjaan Indonesia Agustus 2019," Jakarta, 2019.

[2] N. M. Lyau, S. Zahro, and D. Nurhadi, "Labor market outcomes for senior secondary school graduates in indonesia," in Advances in Social
Science, Education and Humanities Research, 2019, vol. 242, pp. 147-149, doi: 10.2991/icovet-18.2019.37.

[3] S. Sukardi, W. Wildan, and M. Fahrurrozi, "Vocational education: A missing link for the competitive graduates?," Int. Educ. Stud., vol. 12, no. 11, pp. 26-35, 2019, doi: 10.5539/ies.v12n11p26.

[4] M. Xu, J. M. David, and S. H. Kim, "The fourth industrial revolution: Opportunities and challenges," IJFR, vol. 9, no. 2, p. 90, 2018, doi: 10.5430/ijfr.v9n2p90.

[5] Willis Towers Watson, "The future of work: from myths to new workplace realities. 2017-2018 global future of work survey," 2018. www.appgai.org/wp-content/uploads/2018/05/fowglobal-survey-results.pdf (accessed Jan. 14, 2020).

[6] J. Vacek, "On the road: From industry 4.0 to society 4.0," Trendy v Podn. / Bus. Trends, vol. 7, no. 4, pp. 43-49, 2017.

[7] M. Gadd, N. Garbellini, and F. Garibaldo, "Industry 4.0 and its consequences for work and labour. Field research report on the implementation of Industry 4.0 in a sample of Italian companies,” 2017. www.fondazionesabattini.it/download/7 43 (accessed Jan. 14, 2020).

[8] Y. Nuraeni and Y. T. Suwadji, "Strategy for enhancing quality of labor through technical vocational education \& training faces industry 4.0 challenges," in The $2 n d$ International Conference on Elementary Education, Bandung, Mar. 2020, vol. 2, 2020, pp. 1255-1272, [Online]. Available:

http://proceedings.upi.edu/index.php/ice e/article/view/742.

[9] Ministry of Education and Culture of the Republic of Indonesia, "Kilasan Dua Tahun Revitalisasi Sekolah Menengah Kejuruan September 2016-2018," Jakarta, 2018. 
[10] J. Midgley, Social Development: The Developmental Perspective in Social Welfare. London: Sage Publication, 1995.

[11] J. Midgley, Social Development: Theory and Practice. 55 City Road, London: SAGE Publications Ltd, 2014.

[12] GRI UN Global Compact and WBCSD, "SDG Compass: The guide for business action on the SDGs," GRI, UN Global Compact, and the WBCSD, 2015. https://sdgcompass.org/wpcontent/uploads/2015/12/019104_SDG_ Compass_Guide_2015.pdf (accessed Jan. 14, 2020).

[13] Apindo and GIZ, Dari CSR Menuju Bisnis Inklusif. Jakarta: Apindo, 2016.

[14] M. J. D. Hopkins, "Corporate social responsibility (CSR) and the united nations sustainable development goals (SDG): The role of the private sector," 2016. [Online]. Available: https://www.csrfi.com/wpcontent/uploads/2013/10/CSR-and-theUnited-Nations-SDGs.pdf.

[15] ISO, ISO 26000: Guidance on Social Responsibility. Geneva: ISO, 2010.

[16] A. Fink, Conducting Research Literature Reviews: From the Internet to Paper, 2nd editio. Thousand Oaks CA: Sage, 2005.

[17] C. Okoli, "A guide to conducting a standalone systematic literature review," CAIS, vol. 37, no. 43, pp. 879-910, 2015, doi: 10.17705/1CAIS.03743.

[18] Cabinet Secretariat of the Republic of Indonesia, Instruksi presiden nomor 9 tahun 2016 tentang revitalisasi sekolah menengah kejuruan dalam rangka peningkatan kualitas dan daya saing sumber daya manusia Indonesia. Indonesia, 2016.

[19] Ministry of Industry Republic of Indonesia, Peraturan menteri perindustrian nomor 03/M-IND/PER/ 1/2017 tentang pedoman pembinaan dan pengembangan sekolah menengah kejuruan berbasis kompetensi yang link and match dengan industri. Indonesia, 2017.

[20] Cabinet Secretariat of the Republic of Indonesia, Peraturan pemerintah nomor 45 tahun 2019 tentang perubahan atas peraturan pemerintah nomor 94 tahun 2010 tentang penghitungan penghasilan kena pajak dan pelunasan pajak penghasilan dalam tahun berjalan. Indonesia, 2019.

[21] R. Aisyah, "Super Tax Deduction Welcomed," The Jakarta Post, Jakarta, Jul. 12, 2019.

[22] A. Okoye, Legal Approaches and Corporate Social Responsibility: Towards A Llewellyn's Law-Jobs Approach. New York: Routledge, 2017.

[23] A. C. Edi, "Cross-sector partnerships models in corporate social responsibility to implement poverty reduction initiatives in Indonesia," Bisnis Birokrasi $J$, vol. 21, no. 2, 2015, doi: 10.20476/jbb.v21i2.4326.

[24] Cabinet Secretariat of the Republic of Indonesia, Undang-undang nomor 40 tahun 2007 tentang perseroan terbatas. Indonesia, 2007.

[25] Cabinet Secretariat of the Republic of Indonesia, Undang-undang nomor 25 tahun 2007 tentang penanaman modal. 2007.

[26] Cabinet Secretariat of the Republic of Indonesia, Peraturan pemerintah nomor 47 tahun 2012 tentang tanggung jawab sosial dan lingkungan perseroan terbatas. 2012.

[27] P. O. Anifowose and E. A. Ohu, "Social Intrapreneurs: Rebels for Good," in In Social Entrepreneurship and Corporate Social Responsibility, J. Marques and S. Dhiman, Eds. Cham: Springer International Publishing, 2020, pp. 99115.

[28] M. A. L. Agudelo, L. Jóhannsdóttir, and B. Davídsdóttir, "A literature review of the history and evolution of corporate social responsibility," Int. J. Corp. Soc. 
Responsib., vol. 4, no. 1, 2019, doi: 10.1186/s40991-018-0039-y.

[29] D. Sulaeman and L. Mona, "Sekolah kejuruan sebagai corporate social responsibility djarum foundation," Wacana, vol. 16, no. 2, pp. 264-278, 2017, doi: 10.32509/wacana.v16i2.35.

[30] M. A. Ramadhani and E. Rahayu, "Competency improvement through internship: An evaluation of corporate social responsibility program in vocational school," IJERE, vol. 9, no. 3, pp. 625-634, 2020, doi: 10.11591/ijere.v9i3.20571.

[31] G. Rusten, G. M. Grimsrud, and K. E. Eriksen, "Corporate Social Responsibility, Education, And Job Training," in Social Entrepreneurship and Corporate Social Responsibility, J. Marques and S. Dhiman, Eds. Cham: Springer International Publishing, 2020, pp. 343-359.

[32] G. Spoettl and V. Tūtlys, "Education and training for the fourth industrial revolution," J. Pendidik. Teknol. dan Kejuru., vol. 26, no. 1, pp. 83-93, 2020, doi: 10.21831 /jptk.v26i1.29848.

[33] A. Durmuş and A. Dağli, "Integration of vocational schools to industry 4.0 by updating curriculum and programs," Int. J. Multidiscip. Stud. Innov. Technol., vol. 1, no. 1, 2017.

[34] M. A. Camilleri and T. Nisar, "Reconceiving corporate social responsibility for business and educational outcomes," Cogent Bus. Manag., vol. 3, no. 1, 2016, doi: 10.1080/23311975.2016.1142044.

[35] P. Deskhmukh, "Corporate social responsibility and education sector: Issues and remedies," Int. J. Manag., vol. 8, no. 1, pp. 137-144, 2017.

[36] Ministry of Education and Culture of the Republic of Indonesia, Grand Design Pengembangan Teaching Factory dan Technopark di SMK. Jakarta: Direktorat Jenderal Pendidikan Dasar dan
Menengah, 2016.

[37] World Economic Forum, "The future of jobs: Employment, skills, and workforce strategy for the fourth industrial revolutions," 2016. [Online]. Available: www3.weforum.org/docs/WEF_Future of_Jobs.pdf.

[38] D. Guile and M. Young, "Beyond the Institution of Apprenticeship: Towards A Social Theory of Learning as The Production of Knowledge," in Apprenticeship Towards A New Paradigm of Learning, P. Anley and H. Rainbird, Eds. London: Kogan Page Limited, 1999, pp. 111-128.

[39] Ministry of Education and Culture of the Republic of Indonesia, Undang-undang RI No. 20 Tahun 2003 tentang Sistem Pendidikan Nasional. Indonesia, 2003.

[40] Ministry of Education and Culture of the Republic of Indonesia, Keputusan menteri pendidikan dan kebudayaan nomor 323/U/1997 tentang penye lenggaraan pendidikan sistem ganda pada sekolah menengah kejuruan. Indonesia, 1997.

[41] Cabinet Secretariat of the Republic of Indonesia, Undang-undang nomor 13 tahun 2003 tentang ketenagakerjaan. Indonesia, 2003.

[42] Ministry of Manpower of the Republic of Indonesia, Peraturan menteri ketenagakerjaan nomor 6 tahun 2020 tentang penyelenggaraan pemagangan di dalam negeri. Indonesia, 2020.

[43] K. Höckel, "Bridging the Gulf Between the World of Work and the World of Learning: Vocational Education and Training in Comparative Perspective," in The Future of Vocational Education and Training in A Changing World, M. Pilz, Ed. Wiesbaden: VS Verlag für Sozialwissenschaften, 2012, pp. 537560.

[44] Sutikno, Baedhowi, Siswandari, and Roemintoyo, "Concept of e-mon prakerinmodel for internship monitoring 
in vocational high school," IOP Conf.

Ser. Earth Environ. Sci., vol. 243, 2019, doi: 10.1088/1755-1315/243/1/012119.

[45] R. F. Aqli, B. Hasan, and T. Sucita, "Internship program as a part of technical and vocational education training (TVET)," Adv. Soc. Sci. Educ. Humanit. Res., vol. 299, 2019, doi: 10.2991/ictvet18.2019.108.

[46] E. H. Oakes, Ferguson Career Resource Guide to Apprenticeship Programs, Third Edit. New York: Ferguson, 2006.

[47] A. Fuller and L. Unwin, "A Sense of Belonging: The Relationship Between Community and Apprenticeship," in Apprenticeship Towards A New Paradigm of Learning, P. Anley and $\mathrm{H}$. Rainbird, Eds. London: Kogan Page Limited, 1999, pp. 150-162.

[48] L. Filliettaz, "Guidance as an Interactional Accomplishment PracticeBased Learning within the Swiss VET System," in Learning through Practice: Models, Traditions, Orientations and Approaches, S. Billett, Ed. Dordrecht: Springer Netherlands, 2010, pp. 156179.

[49] M. Eraut, "Knowledge, Working Practices, and Learning," in Learning Through Practice: Models, Traditions, Orientations and Approaches, S. Billett, Ed. Dordrecht: Springer Netherlands, 2010, pp. 37-58.

[50] H. Worthen and M. Berchman, "Apprenticeships: What Happens in Onthe-Job Training (OJT)?," in Learning Through Practice: Models, Traditions, Orientations and Approaches, S. Billett, Ed. Dordrecht: Springer Netherlands, 2010, pp. 222-239.
[51] D. Anggraeni, "Management of internship program (prakerin) on accounting competency in SMK negeri 2 Pekalongan," Universitas Negeri Semarang, 2017.

[52] D. Ariyanti, "Evaluation of internship in SMK negeri 1 Sayung," Universitas Kristen Satya Wacana, 2015.

[53] K. Armstrong, M. Parmelee, S. Santifort, J. Burley, and W. van Fleet, "Preparing tomorrow's workforce for the Fourth industrial revolution for business: A framework for action," 2018.

[54] L. Rentzos, D. Mavrikios, and G. Chryssolouris, "A two-way knowledge interaction in manufacturing education: The teaching factory," Procedia CIRP, vol. 32, pp. 31-35, 2015, doi: 10.1016/j.procir.2015.02.082.

[55] L. Rentzos, M. Doukas, D. Mavrikios, D. Mourtzis, and G. Chryssolouris, "Integrating manufacturing education with industrial practice using teaching factory paradigm: A construction equipment application," Procedia CIRP, vol. 17, pp. 189-194, 2014, doi: 10.1016/j.procir.2014.01.126.

[56] G. Chryssolouris, D. Mavrikios, and L. Rentzos, "The teaching factory: A manufacturing education paradigm," Procedia CIRP, vol. 57, pp. 44-48, 2016, doi: 10.1016/j.procir.2016.11.009.

[57] P. Kotler and N. Lee, Corporate Social Responsibility: Doing the Most Good for Your Company and Your Cause. New Jersey: John Wiley \& Sons, Inc, 2005.

[58] A. Crane, D. Matten, and L. Spence, Corporate Social Responsibility: Readings and Cases in A Global Context, Second Edi. New York: Routledge, 2014. 